〈JAROS2016 研究発表大会ルポ 2016 年 11 月 19 日(土) 20日（日）於：中央大学後楽園キャンパス〉

\title{
JAROS 創立十周年記念大会ルポ
}

\author{
佐藤 公俊 \\ (神奈川大学工学部)
}

\section{1. はじめに}

2016 年 11 月 19 日と 20 日の 2 日間にわたり、日本 リアルオプション学会 2016 年研究発表大会が中央大 学後楽園キャンパスで開催された。本学会は 2006 年 からスタートし、本年度は創立十周年記念の年にあ たるため、シンポジウム、パネルディスカッション、 チュートリアル・セッション等の特別企画が行われ た。本大会は日本感性工学会協賛の大会であり、鳥海 重喜実行委員長 (中央大学) を筆頭に準備を実行委員 会で進め、2 日間で 80 名を超える方に参加頂いた。

\section{2. シンポジウム}

大会初日（11/19）では、「リアルオプションが挑む 価值創造のフロンティア」というテーマで 3 件の講 演が行われた。司会の今井潤一氏（慶應義塾大学）上 りテーマの趣旨説明の後、講演 1 として、森平爽一郎 氏 (早稲田大学) から「リアルオプション研究の新し い方向をめざして」というタイトルで講演が行われ た。リアルオプションの事例として、貨幣、大災害、 アスリートの報酬、航空の搭乗率保障などが紹介さ れるとともに、その価格決定理論としてプライシン グ・カーネル法が有効であることが述べられた。リア ルオプションが様々な分野に広がりを持ち、今後の 発展性を示されたことは大変興味深かった。

続いて講演 2 として、伊藤剛氏（アクセンチュア (株)）から「破壊的イノベーションと電気事業のビ ジネスモデル変革」というタイトルで講演が行われ た。電気の発電から流通、小売における各事業におけ る新たなテクノロジーを用いたビジネスモデルが事 例とともに紹介された。

続いて講演 3 として、堀江貞之氏（(株）野村総合 研究所）から「二つのコードと企業価值向上」という タイトルで講演が行われた。企業経営者が果たす心゙ き役割は長期の企業価值向上であるが、機関投資家 はこの役割をどのように達成してほしいと考えてい るかについて事例を基に紹介された。

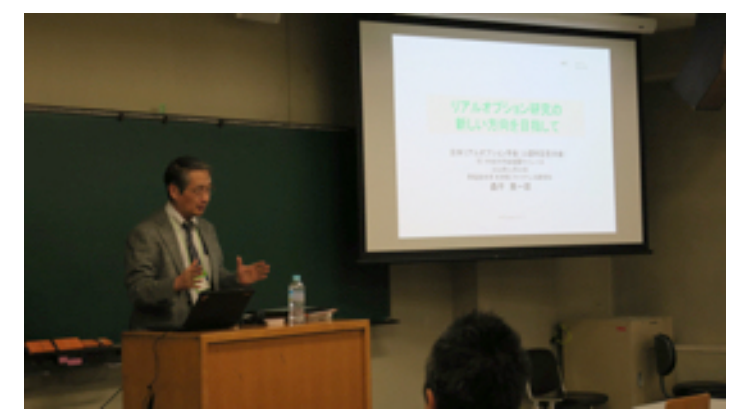

森平氏によるシンポジウムの様子（撮影 : 伊藤真理氏）

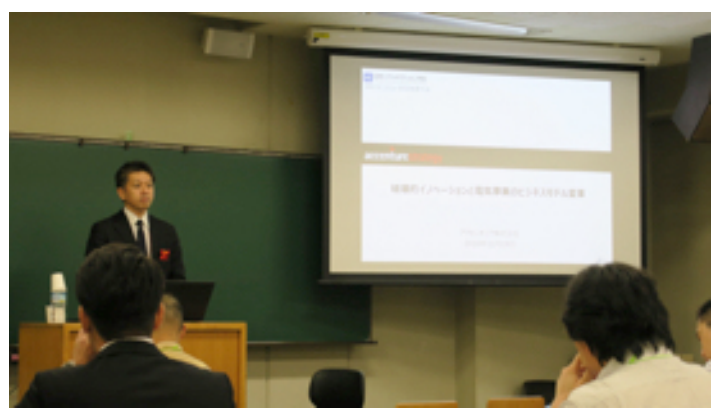

伊藤氏によるシンポジウムの様子（撮影 : 伊藤真理氏）

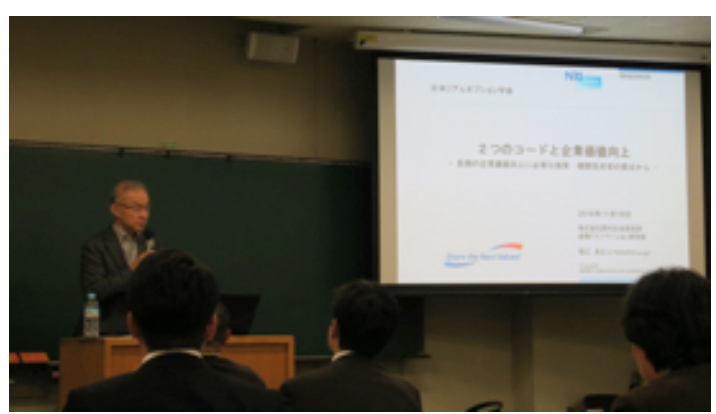

堀江氏によるシンポジウムの様子（撮影 : 伊藤真理氏）

\section{3. パネルディスカッション}

パネルディスカッションでは、「リアルオプション 学会の原点とこれからのフロンティア」というテー マで高森寛氏の司会のもと、長谷川専氏（(株）三菱 総合研究所)、今井潤一氏 (慶應義塾大学)、北原康富 氏 (名古屋商科大学大学院)、小林孝明氏（(株）野村 総合研究所) による討論が行われた。本学会の前身で 
あり 2002 年に始まった月例公開研究会「金融技術と 経営戦略」の当時の様子が語られるとともに、学会創 設当初の有志の方々の志を聞くことができた。さら に、これからの日本の経営と経済に対して、本学会が どのようにチャレンジし、貢献することができるか についての活発な意見が交わされた。

シンポジウムの各講演者の講演内容とパネルディ スカッションでの内容については本機関紙に掲載さ れているのでそちらを参照されたい。

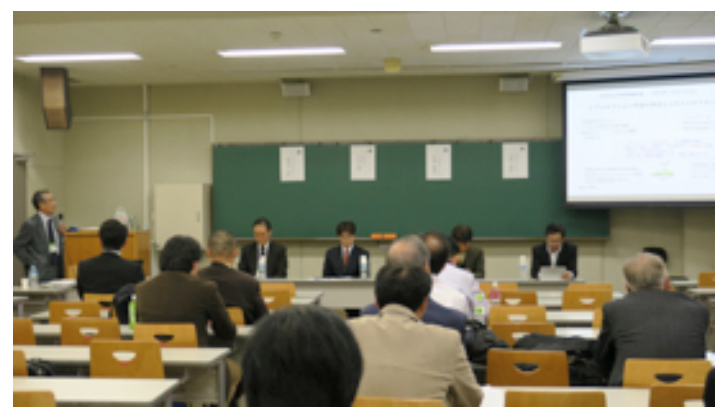

パネルディスカッションの様子（撮影：伊藤真理氏）

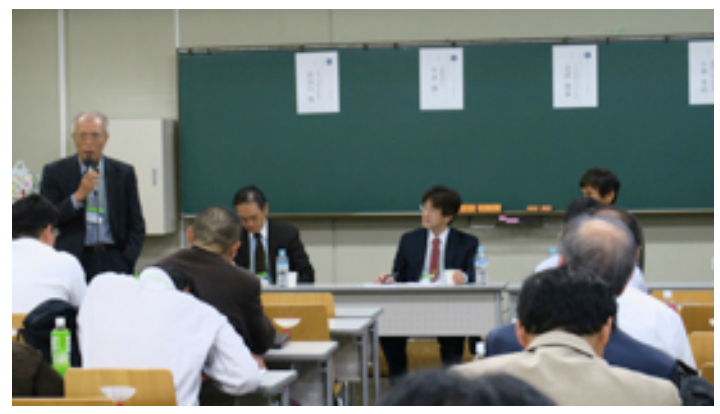

パネルディスカッションの様子（撮影 : 伊藤真理氏）

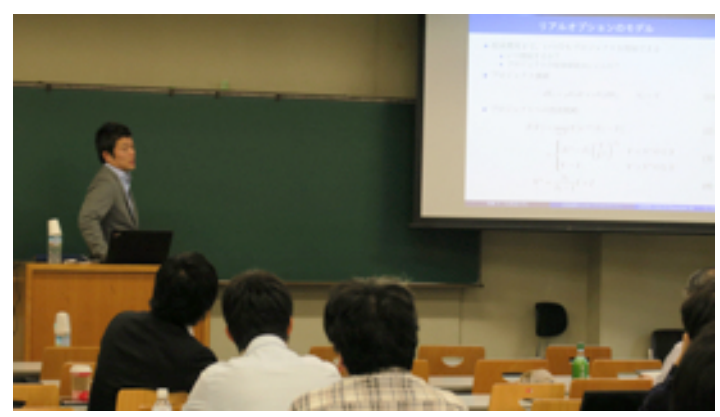

後藤氏によるチュートリアルの様子（撮影：伊藤真理氏）

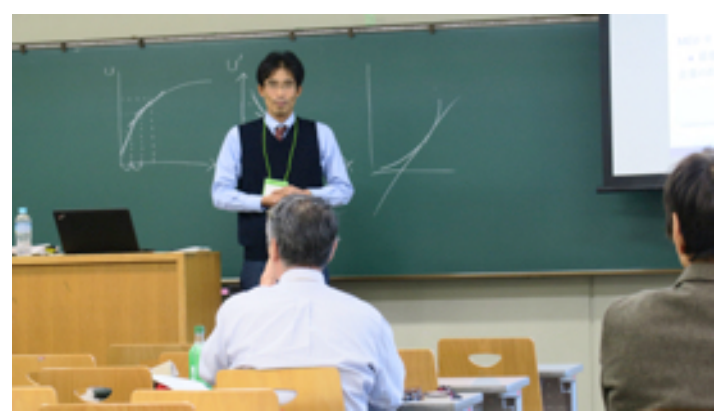

辻村氏によるチュートリアルの様子（撮影：伊藤真理氏）

\section{4. チュートリアル}

2 日目 $(11 / 20)$ の午前に行われたチュートリアルで は、後藤允氏 (北海道大学) 、辻村元男 (同志社大学)、 高嶋隆太氏（東京理科大学）の3名により、学生・大 学院生を対象としたリアルオプションの講義が行わ れた。

後藤氏の講義では、リアルオプションの基礎概念 が四則演算のみを用いてわかりや寸く解説された。 難解な数式を用いずリアルオプションの本質を学ぶ ことができるため、大学生だけでなく、高校生への教 材としても活用できる内容であった。

辻村氏の講演では、曖昧さ (ambiguity) を想定した もとでの投資の意思決定方法が解説され、最新のリ アルオプション分析に触れることができた。

また、高嶋氏によるリアルオプションの経済実験 では、工場の設置に関する投資プロジェクトを例と したゲームが行われた。投資後に得られるキャッシ ユフローが不確実に変化する際に、プレーヤーは投 資を実施するべきか延期すべきかを選択し、高い利 潤を目指すというものである。ゲームを通して、不確 実性と意思決定を楽しく体験することができた。

\section{5. 一般報告}

一般セッションと查読セッションでは計 15 件の研 究発表が行われ、活発な議論がなされた。例えば、董 晶輝氏 (東洋大学) は「最適閾値への初到達時間の比 較静学分析」では、将来のキャッシュフローが幾何ブ ラウン運動に従う場合に、参入および退出の際の最 適閾値一の初期到達時間に関する比較静学の結果が 定性的に示された。また、伊藤晴祥氏（国際大学大学 院）による「2 変数をトリガーとする天候デリバティ ブを利用したリスクマネジメント」では、コピュラ関 数を用いて気温および降水量の 2 つのリスク変数の 相関構造を考慮し、実データを用いて天候リスクマ ネジメントの価值分析を行うという内容であった。

また、本大会では、創設十周年を記念して研究発表 奨励賞が設けられ、伊藤和哉氏 (東京理科大学) の「複 占競争下における企業の投資意思決定一リスク回避 度の影響一」に授与された。この研究では、複占市場 の意思決定主体のリスク回避度が非対称であるとき、 コストとリスク回避度の変化が投資のタイミングに 与える影響を分析している。リスク回避度の大きさ と企業の市場参入のインセンティブの関係や投資の 閾值の比較静学が細かく分析されており、興味深い 内容であった。 


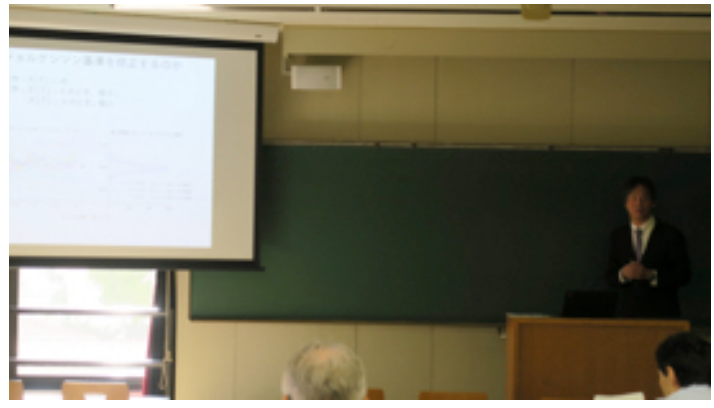

董氏による研究発表の様子（撮影 : 伊藤真理氏）

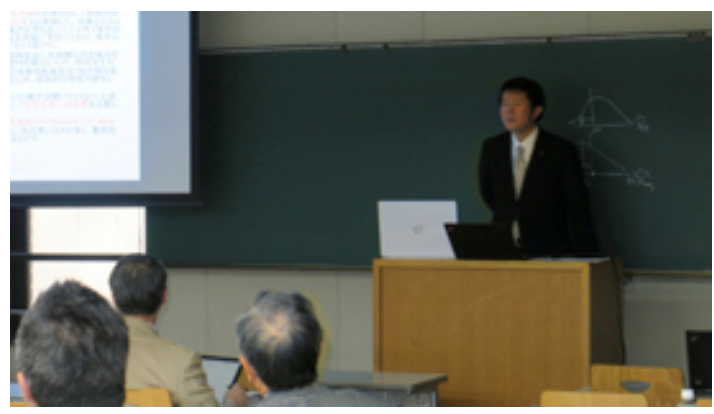

伊藤氏による研究発表の様子（撮影：伊藤真理氏）

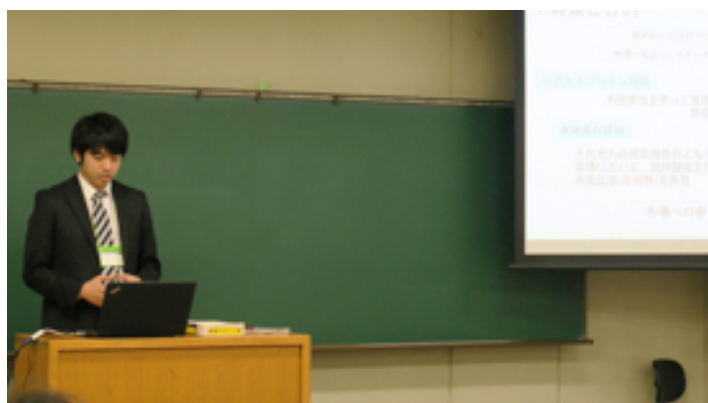

研究発表奨励賞を受賞された伊藤氏（撮影 : 伊藤真理氏）

\section{6. 㤠親会}

懇親会は中央大学後楽園キャンパス内の会議室で 開催された。35 名の方に参加していただき、大変盛 況だった。服部徹会長（(一財）電力中央研究所）の ご挨拶に始まり、続いて、中央大学理工学部長の石井 靖氏よりご挨拶をいただいた。今井潤一副会長の乾 杯のご発声後、ビュッフェ形式で懇親会はスタート した。会場には、食べきれないほどたくさんの料理が 並んでいた。

懇親会の中盤では、本学会創設時の前身にあたる 研究会から現在まで長年ご尽力いただいている高森 寛氏が本学会で最初の名誉会員として表彰された。 スピーチでは、産業界と学術界が結びつき今後の学 会の発展を期待する旨が述べられ、大変印象深いも のであった。

また、本大会の懇親会には多くの法人会員の方々 にご参加いただいた。新規法人会員を代表して、二宮

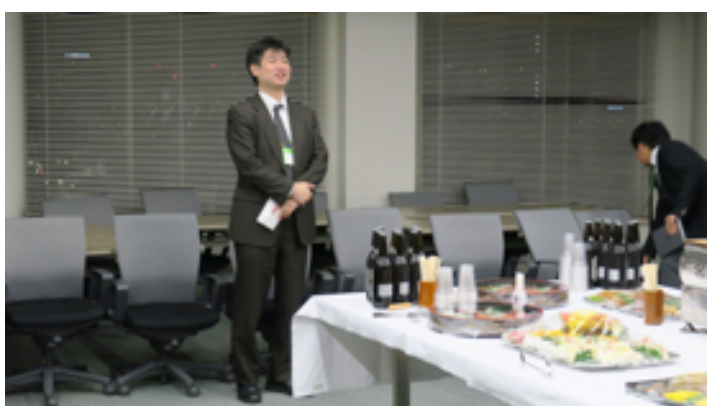

服部会長氏による挨拶の様子（撮影：伊藤真理氏）

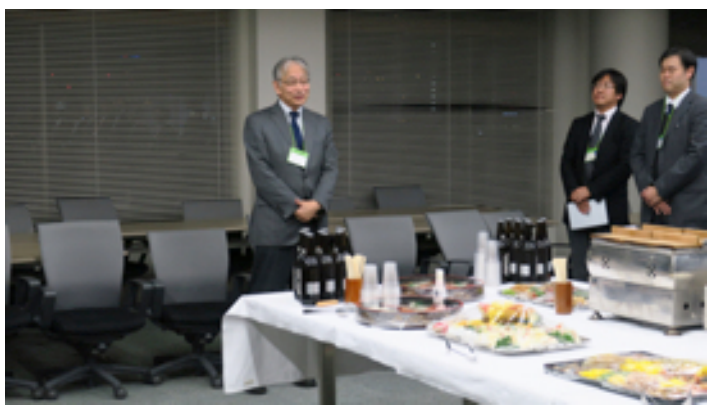

石井氏（左）と副実行委員長の高嶋氏（中央）、実行委員 長の鳥海氏（右）（撮影：伊藤真理氏）

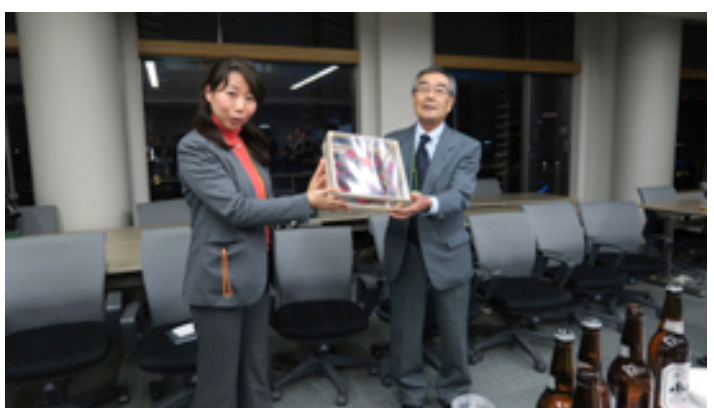

高森氏（右）と伊勢氏（左）（撮影 : 伊藤真理氏）

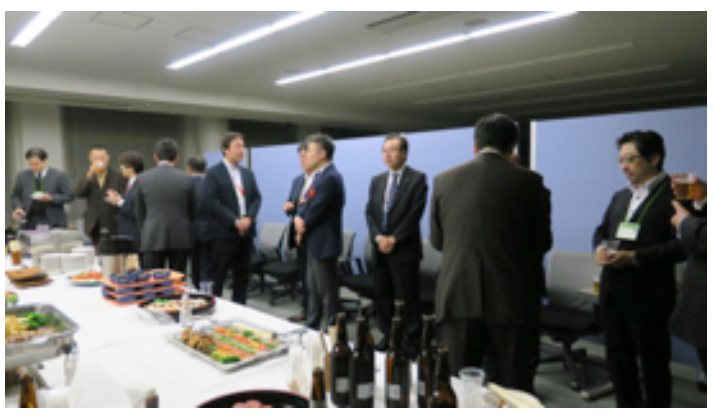

懇親会の様子（撮影 : 伊藤真理氏）

俊一郎氏（(株）翻訳センター）と松浦正二氏（(株) サンセイランディック) にご挨拶をいただいた。二宮 氏は学会を通じたビジネスマッチングの魅力につい て述べられ、松浦氏からは学会における受託研究に 対する期待が述べられた。懇親会を通して、産学の交 流を深めるよい機会となった。 


\section{7. おわりに}

2 日間にわたる本研究発表大会は参加者が活発に 交流を深める非常に有意義なものでした。これは実 行委員長の鳥海先生をはじめ開催準備にかかわった 諸先生方、参加・ご講演頂いたすべての方々、ならび
に関係各位のご支援とご協力のおかげであり、参加 者を代表して心より感謝申し上げます。また、本研究 発表会が今後のリアルオプションのさらなる発展へ 貢献することを期待しております。

\section{JAROS2017 研究発表大会へのご案内}

期間：2017年 11 月 25 日、26日（土日開催）

場所 : 石川県政記念 しいの木迎賓館 石川県金沢市広坂 2-1-1

発表申込: 2017 年 3 月 受付開始 予定

参加申込: 2017 年 6 月 受付開始 予定

予定セッション

一般研究報告、查読セッション、シンポジウム：基調講演、チュートリアルセッショ

ン、懇親会

実行委員会（敬称略）

実行委員長 : 佐藤 清和

副実行委員長：長谷川 專, 高嶋隆太

プログラム委員長: 辻村 元男

実行委員 : 伊藤 晴祥、伊藤 真理、小巴潤一郎、後藤 允、佐藤 公俊、鈴木 広人、

鈴木 正昭、高森 寛、内藤 優太、小林 孝明、松尾 雄治、服部 徹、伊勢 美里

\section{論文誌「リアルオプション研究」原稿募集のご案内}

日本リアルオプション学会は、查読付論文誌「リアルオプション研究」(英文名称： Journal of Real Options and Strategy) を発刊しております。本論文誌は、電子ジャーナル化されて、国内外に広く、公 開されております。

$$
\text { https://www.jstage.jst.go.jp/browse/realopn }
$$

\section{募集する原稿:}

リアルオプションおよびこれに関連する経営科学、リスクマネジメント、オプション的資産の価值、投資 戦略、ゲームと戦略などについての理論、実証および応用に関する研究のほかケーススタディーィ、ある いは、この分野における教育方法の改善などに関する和文の論文で、新規性または、有用性のあるもの。

投稿原稿は、次の 3 類型に分けて審査されます。
1. 理論研究
2. 応用研究
3. 研究ノート 